\title{
Influence of Problem Based Learning Model on Thinking Skills Critical and Student Learning Outcomes Elementary School
}

\author{
Didik Setyono, Ketut Prasetyo, and Muhammad Yani Turhan \\ Pascasarjana: Pendidikan Dasar \\ Universitas Negeri Surabaya \\ Surabaya, Indonesia \\ dsetyono99@gmail.com
}

\begin{abstract}
Critical thinking is skills that must trained from basic education because can give a good effect and benefit the higher education, while learning results obtained by students during follow lessons schools. The research objective is analyze impact Problem Based Learning model on thinking skills critical and learning outcomes in Social Sciences $4^{\text {th }}$ grade students in Elementary School of Islam Nurul Hikmah Lebakadi village Sugio district, Lamongan regency. The research is quantitative experiment using Quasi Experimental Design model. The results showed significant influence between Problem Based Learning model on thinking skills critical and learning outcomes in Social Sciences $4^{\text {th }}$ grade students in Elementary School of Islam Nurul Hikmah Lebakadi village Sugio district, Lamongan regency. The effect is also to prove that Problem Based Learning model is very effectively applied to learning process of Social Sciences at the Elementary School level.
\end{abstract}

Keywords-Problem Based Learning, thinking skills critical, learning outcomes

\section{INTRODUCTION}

Law of Republic Indonesia Number 20 Year 2003National Education System, has stated that nationwide general purpose of education is in addition to developing the students' ability to be virtuous, knowledgeable, creative and independent, also seeks to create personalized every citizen to become individuals that democratic and responsible [1]. Understanding of above makes it clear that education is central to improving quality of human resources for being able to contribute progress a nation, as well as a vehicle for interaction in delivery of messages based on constitution, as well support facilities in building character and identity of an independent and sovereign nation.

The learning activities in schools will be run as if between students and teachers has been a process of active interaction. In this interaction process, task a teacher is not just a central activity of existing system teaching and learning in schools, but more concerned with active involvement of all students in learning. Therefore, in creating these conditions, a teacher must be creative in controlling learning activities, by means mastering material and application methods and techniques of learning approaches that appropriate materials to students about given.

Through interviews with Munghidlotul Ummah as teachers teaching Social Sciences and observations that have researchers dated September 12, 2017 in SD Islam Nurul Hikmah Lebakadi village Sugio district, Lamongan regency in fourth grade the first semester, about the social and cultural diversity and natural appearance showed in teaching process, teachers in classroom teaching model has been used Contextual Teaching Learning (CTL). As we know that CTL learning model is a teaching technique that can help students see academic material studied by examining relationship between academic subjects with realities of everyday life, such as relationships themselves are personal circumstances and socio-cultural being faced.

By showing the CTL model that is still bound by ability of teachers, so that in teaching system learners look less responsive to lesson. Such problems ultimately lead to students' thinking skills critical are still less than optimal and students have difficulty understanding what has been learned, resulting in low learning outcomes obtained by some learners. The average score achieved by students from learning outcomes during Sosial Science (IPS) lesson using CTL technique is said to be low, because there are $63.64 \%$ or as many as 14 students who score below 70. As for "Kriteria Ketuntasan Minimal" (KKM) in lesson IPS in $4^{\text {th }}$ grade of SD Islam Nurul Hikmah, this amounted to 70 and only reached $36.36 \%$ or as many as 8 students.

Efforts to stimulate students to think critically, logically and effectively is crucial. Learning implemented should grow and develop creativity and critical thinking skills to train students in learning as well as in solving the problems faced in the routine of life. The ability of people to think critically about problems that arise are much needed in everyday life, because eventually the thinking skills critical can be used to make a decision in solving problems in society. Critical thinking as ability also is a skill that must be nurtured and developed and trained ranging from basic education.

One effort to improve on thinking skills critically in order to obtain a high learning outcomes in subject of Social Sciences which researchers use as a model of learning, namely Problem Based Learning. Researchers chose SD Islam Nurul Hikmah Lebakadi village Sugio district, Lamongan regency as a place of research, a result of learning from some students that researchers discovered through observation in this school showed the value of which still low compared to number of students that much.

Based on description of background problem, so it can be formulated that problems this study, among other things: 1) What is effect of Problem Based Learning model on thinking skills critical in subject Social Sciences $4^{\text {th }}$ grade students?; 2) What is 
effect of Problem Based Learning model on learning outcomes in subject Social Sciences $4^{\text {th }}$ grade students?; and 3) What is effect of Problem Based Learning model on thinking skills critical and learning outcomes in subject Social Sciences $4^{\text {th }}$ grade students? While the goal of this research are: 1) To analyze influence of Problem Based Learning model on thinking skills critical in subject Social Sciences $4^{\text {th }}$ grade students; 2) To analyze influence of Problem Based Learning model on learning outcomes in subject Social Sciences $4^{\text {th }}$ grade students; and 3) To analyze influence Problem Based Learning model on thinking skills critical and learning outcomes in subject Social Sciences $4^{\text {th }}$ grade students.

The learning model according to Slavin is a reference toan approach to learning, including purpose, syntax, environment, and management system [2]. Meanwhile, in view of Kardi and Nur traits learning model must meet the following criteria: 1) Rational logical compiled by creators or developers; 2) Rationale of what and how students learn (learning objectives to be achieved); 3) Behavior of teaching required so that model can implemented successfully; 4) The learning environment necessary for learning objectives that can be achieved [3].

Problem Based Learning model is actually rooted in John Dewey's view that suggests an educator can teach well should be able to attract attention of students to conduct an investigation and creation. Because it is necessary to have a certain approach in all subjects presented in class. That approach is intended to empower minds of students to have ability learn in an integrated and contextual [4].

Jihad and Haris explained as achievement of learning outcomes a form that can change behavior of cognitive, psychomotor and affective to learning process that occurs at certain times [5]. From opinions and explanation of above can be understood that Problem Based Learning model is applied in process of learning by using authentic and contextual problems for students to solve problems and think critically in order to gain useful knowledge and optimal learning results.

Richard Paul argues that critical thinking is a way of thinking about things that are substantive and involving various problems, where the thinker is trying to increase quality of thinking by handling structure of his thinking skillfully as well as applying intellectual standards inherent in his mind [6]. While the results of study by Robert M. Gagne interpreted as change in human disposition or capacity, which persists over a period of time, and which is not simply ascribable to process a growth

[7]. This opinion implies that learning are all changes taking place in human capacity, which continue all time, and not only can be regarded as a process for growth alone.

Several previous studies, relevant to this research, including research jointly undertaken John R. Mergendoller, Nan L. Maxwell and Yolanda Bellisimo in 2006, entitled "The Effectiveness of Problem-Based Instruction: A Comparative Study of Instructional Methods and Student Characteristics". This research shows the use of Problem Based Learning model more good and effective when compared to traditional methods relating to teaching model in schools [8]

Research conducted by Behiye Akçay entitled "Problem Based Learning in Science Education". The study produced purport back on Problem Based Learning as an educational approach that challenges students to work cooperatively in groups to seek solutions to real world problems and develop skills to become independent learners. More student-centered instruction and learning more active and not passive. Teachers play some role as a facilitator and coach [9].

The previous study, entitled "Implications of Problem Based Learning (PBL) in Elementary Schools upon the K-12 Engineering Education Pipeline", by Daniel Tillman in 2013. The results showed that PBL students reported a higher level of collaboration significantly, which means they work with and help their peers more than students in traditional teaching, teachers and worksheets focused. More specifically, the students collaborate to solve mathematical problems more than control group, which involves set marketable skills they need to succeed as an engineer and basically in STEM careers [10].

Last previous studies into consideration, namely joint research from Shishigu Aweke Argaw, Beyene Bashu Haile, Tesfaw Ayalew Beyene, and Shiferaw Gadisa Kuma in 2017 entitled "The Effect of Problem Based Learning (PBL) Instruction on Students Motivation and Problem Solving Skills of Physics". This study shows differences statistically significant with effect sizes above average. However, the difference to learn physics revealed no significant [11].

The success of learning and teaching can be measured from results of student learning, because learning outcomes achievement of a form that can change behavior of cognitive, psychomotor and affective aspects of the learning process that occurs at certain times. So that teachers and other educators must have a strategy in order to achieve maximum learning outcomes in educational environment, assessment of learning outcomes have significance both for teachers and schools.

From some opinions and description above can be understood that Problem Based Learning is a model applied in learning process by using problems that are authentic and contextual for students to solve problems and think critically in order to get useful knowledge and optimal learning outcomes. Therefore, Problem Based Learning as a model in learning has relevance with ability to think critically and has real benefits in improving student learning outcomes created from understanding of science itself.

\section{METHODOLOGY}

The type used is quantitative experiment, which aims to determine accurately influence on use of Problem Based Learning model on thinking skills critical and student learning outcomes. The design of study is Quasi-Experimental Design, which is an experiment that has treatment, impact measurement, and units of experiment but did not use random assignment to create a comparison in concluding changes caused treatment. The study design was used Nonequivalent Control Group Design, which is almost the same as the pretest-posttest control group design. Only in this design the experimental class and control class is not chosen randomly. The design is described as follows: 
Figure 1: Design Research

\begin{tabular}{|lll|}
\hline $\mathrm{O}_{1}$ & $\mathrm{X}$ & $\mathrm{O}_{2}$ \\
$\mathrm{O}_{3}$ & & $\mathrm{O}_{4}$ \\
\hline
\end{tabular}

\section{Information:}

$\mathrm{O}_{1}$ : pretest result to experiment class

$\mathrm{O}_{2}$ : posttest result to experiment class

$\mathrm{O}_{3}$ : pretest result to control class

$\mathrm{O}_{4}$ : posttest result to control class

$\mathrm{X}$ : treatment that applying the PBL model [12]

Respondents in the study of all students in IVA class which totaled 22 people and IVB class numbered 22 people. To measure ability of their earlier done by giving pretest. Researchers used a pretest to determine condition of respondents who researched before being given treatment that is lesson of Social Sciences by using of Problem Based Learning model. After respondents were given treatment model of Problem Based Learning, then posttest that results are used to determine effect of treatment results using of Problem Based Learning model on results of treatment using CTL model.

In conducting research should use instruments form facilities and equipment used to collect data. The instruments used in data collection here form observations and tests. Observation and tests conducted by researchers using same instrument in experiment class and control class [13]. Objective tests given in control class and experiment class. Giving pretest questions to class control and experiment class were carried out before study conducted, which aim early to determine ability of students. While provision of post-test questions to both classes do after getting treatment form Problem Based Learning models for experiment class and control class for CTL model learning, It aims to determine the condition of the end of second grade.

It research uses empirical validity for validation instruments are prepared and assayed by experience. Meanwhile, in analyzing validity items each question, researchers used a formula of Product Moment. According Winarsunu Product Moment correlation test was discovered by Karl Pearson and used describe relationship between two variables equally manifold interval and ratio. To calculate value of Product Moment Correlation can use following formula:

$$
r_{x y}=\frac{\mathrm{N} \sum \mathrm{XY}-\left(\sum \mathrm{X}\right)\left(\sum \mathrm{Y}\right)}{\sqrt{\left\{N \sum X^{2}-\left(\sum X\right)^{2}\right\}\left\{N \sum Y^{2}-\left(\sum Y\right)^{2}\right\}}}
$$

\section{Information:}

$r_{x y} \quad:$ Validity items

$\mathrm{N} \Sigma \mathrm{XY}$ : Test scores on items sought validity

$\Sigma \mathrm{X}:$ : Score a matter which is achieved through the test

$\Sigma \mathrm{Y} \quad$ : The number of students, who test,

Decision rule is: if $r_{\text {count }}>r_{\text {table }}$ at significance level of $5 \%$ means that item was valid, and if $\mathrm{r}_{\text {count }}<\mathrm{rtable}_{\text {ab }}$ at significance level of $5 \%$ means that the item was not valid.
Test data is further ie reliability test to designate level of reliability of an instrument, something enough instrumentscan be trusted to be used as a means of collecting data for instrument is good. In measuring level of reliability by using Cronbach's Alpha method according formula following:

$$
r_{11}=\frac{k}{(k-1)}\left(1-\frac{\sum o_{b}{ }^{2}}{\dot{o}^{2}{ }_{t}}\right)
$$

\section{Information:}

$r_{11}$ : Reliability of measuring instruments

$k \quad:$ Many items (questions)

$\alpha_{t}^{2}$ : The value of the total variance

$\sum_{i} \sigma_{h}^{2}:$ The number of variants on items,

Advanced testing instruments deployed normality is useful to know the research data is normal or not normal distribution. Normality test is done by calculating value of pretest against pretest values between two groups and value posttest rate against same in both groups. Namely normality test used ChiSquare test with formula:

$$
x^{2}=\Sigma\left[\frac{(f o-f e)^{2}}{f e}\right]
$$

\section{Information:}

$x^{2}=$ Chi-Square value.

$f_{o}=$ Rated frequency results.

$f e=$ The expected frequency value.

Testing criteria used at level of $5 \%$ or 0,05 signifkansi. Priyatno according, normality test criteria is if significance of less than 0,05 , it can be said that data distribution is not normal, but if the significance value of 0,05 , the data can be said to be normally distributed [14].

After conducting tests of normality, then the next is to do analysis of test data starting from homogeneity, is used to determine whether a selected sample have the same variance (homogeneous) or not. Homogeneity test is intended to determine each group a sample (i.e. control class and experimental class) has a homogeneous or inhomogeneous variant. Homogeneity test carried out on the results of the pretest and posttest, by using the following formula:

$$
\operatorname{Varian}\left(S D^{2}\right)=\frac{\sum X^{2}-\left(\sum X\right)^{2} / N}{(N-1)}
$$

Information:

$$
\begin{aligned}
& S D^{2}=\text { value variant } \\
& \Sigma X^{2}=\text { Amount of data } X^{2} \\
& \Sigma X=\text { Amount of data } X \\
& N=\text { Total Entire Data [15]. }
\end{aligned}
$$

Rule set, i.e. if the significance $<0.05$, the variance in the data group is not homogeneous, and if significance of $>0.05$, then the variance in the data is expressed homogeneous group.

After conducting tests of normality and homogeneity, subsequently forwarded to step hypothesis testing. The analysis used to test the hypothesis that if pretest experimental class is no 
different pretest control class, then to test formulation of problem the influence Problem Based Learning model on thinking skills critical and student learning outcomes do TTest between posttest experimental class and posttest control group. The formula used to calculate the t-test of two different classes that control class and experimental class, namely:

$$
T=\frac{M x-M y}{\sqrt{\left(\frac{\sum x^{2}+\sum y^{2}}{N x+N y-2}\right)\left(\frac{1}{N x}+\frac{1}{N y}\right)}}
$$

\section{Information:}

$M=$ The average value per class results

$N=$ A large number of subjects

$x=$ Deviation on the value of variables $X$

$y=$ Deviation on the value of variables $Y 2$ and Y1 [16]

After T-test value is known, then determined degree of freedom with the formula $d b=(N x+N y-2)$ and consult with ttable at 0,05 level of significance. If $t_{\text {count }}>t_{\text {table }}$ it can be concluded that given way that affect thinking skills critical and student learning outcomes and if $t_{\text {count }}<t_{\text {table, }}$ it is known that given way that researchers do not affect the thinking skills critical and student learning outcomes.

The next hypothesis testing that is using F-test to obtain the results influence of Problem Based Learning model on thinking skills critical and student learning outcomes. Sugiyono stated that use of F-test an analysis aimed to test how much influence resulting from independent variables together on the dependent variable being tested. Formula $F$ test (simulants) used in this analysis is:

$$
F=\frac{R^{2} / k}{\left(1-R^{2}\right) /(n-k-1)}
$$

\section{Information:}

$F \quad=$ value $F_{\text {count }}$ and $F_{\text {table value }}$

$R 2=$ Value partial correlations were determined

$n \quad=$ many samples

$k=$ many variable free [17]

There are two ways in decision rule used in determining this test, namely first, compare between value of significance level with value of Alpha 0.05 , the rule is: if $F_{\text {count }}>F_{\text {table }}$ at level of significance 0.05 then $\mathrm{H}_{\mathrm{o}}$ is rejected while $\mathrm{H}_{\mathrm{a}}$ is accepted, and if $F_{\text {count }}<F_{\text {table }}$ at 0.05 significance level then $\mathrm{H}_{\mathrm{o}}$ is accepted while $\mathrm{H}^{\mathrm{a}}$ is rejected. Second, that is comparing value of $F_{\text {count }}$ with $F_{\text {table }}$ value, the rule is if $F_{\text {count }}>\mathrm{F}_{\text {table }}$ then $\mathrm{H}_{\mathrm{O}}$ is rejected and $\mathrm{H}_{\mathrm{a}}$ accepted, whereas if $F_{\text {hitung }}<F_{\text {tabel }}$ then $\mathrm{H}_{\mathrm{o}}$ accepted and $\mathrm{H}_{\mathrm{a}}$ rejected.

\section{RESULTS AND DISCUSSION}

Based on results research that has been done on calculations about the validity test. Researchers used the test result data is calculated by formula Product Moment Correlation. If price $\mathrm{r}_{\mathrm{xy}}>\mathrm{r}_{\text {table }}$ matter be valid with a significant level of $5 \%$. Based on results of a calculation with SPSS version 22 for Windows, has obtained the following results:

\begin{tabular}{|c|c|c|}
\hline Indicator & $\begin{array}{c}\text { Correlation Coefficient } \\
\left(\mathbf{r}_{\text {hitung }}\right) \\
\end{array}$ & Information \\
\hline \multicolumn{3}{|l|}{$\begin{array}{l}\text { Thinking Skills } \\
\text { Critical } \\
\end{array}$} \\
\hline Int erpret & 0,874 & valid \\
\hline Analyzing & 0,776 & valid \\
\hline Evaluat e & 0,856 & valid \\
\hline Referring & 0,782 & valid \\
\hline \multicolumn{3}{|l|}{$\begin{array}{l}\text { Social Study } \\
\text { Subject Matter: }\end{array}$} \\
\hline Problem 1 & 0,698 & valid \\
\hline Problem 2 & 0,672 & valid \\
\hline Problem 3 & 0,654 & valid \\
\hline Problem 4 & 0,721 & valid \\
\hline Problem 5 & 0,577 & valid \\
\hline Problem 6 & 0,607 & valid \\
\hline Problem 7 & 0,623 & valid \\
\hline Problem 8 & 0,626 & valid \\
\hline Problem 9 & 0,713 & valid \\
\hline Problem 10 & 0,578 & valid \\
\hline Problem 11 & 0,832 & valid \\
\hline Problem 12 & 0,826 & valid \\
\hline Problem 13 & 0,570 & valid \\
\hline Problem 14 & 0,530 & valid \\
\hline Problem 15 & 0,764 & valid \\
\hline Problem 16 & 0,495 & valid \\
\hline Problem 17 & 0,724 & valid \\
\hline Problem 18 & 0,652 & valid \\
\hline Problem 19 & 0,861 & valid \\
\hline Problem 20 & 0,615 & valid \\
\hline Problem 20 & 0,615 & valid \\
\hline
\end{tabular}

Table 1: Results of Validity Test

The next test is a reliability test conducted related provision of research instruments in judging something is judged. Reliability test results of thinking skills critical and student learning outcomes, namely:

Table 2: Results of Research Variables Reliability Test

\section{Research Variable Cronbach's Alpha if Item Deleted}

Thinking Skills Critical $\quad 0,714$

Learning Outcomes $\quad 0,816$

Reliability test results on the variables critical thinking skills and student learning outcomes generate value Cronbach Alpha if Item Deleted more than 0,6, so the variables critical thinking skills and learning outcomes of students said to be reliable. 


\section{Normality Test Data}

Normality test performed on data critical thinking skills when given the treatment as well as the pretest and posttest with the aim to determine the normal distribution of data or not. Normality test data is calculated using the chi-square test with the test criteria of normality that is if the significance $<$ 0,05 , the data are not normally distributed, if the significance value $>0,05$, then the normal distribution of data. The test results normality thinking skills critical and learning outcomes in this study as follows:

Table 3: Results of Normality Test Critical Thinking Skills

\begin{tabular}{|l|c|c|c|}
\hline \multicolumn{1}{|c|}{ Group } & Variables & $\begin{array}{c}\text { Chi-Square } \\
\text { Test }\end{array}$ & $\begin{array}{c}\text { Information } \\
\text { (Asymp. Sig. > 0,05) }\end{array}$ \\
\hline Control & Thinking Skills Critical & 0,702 & Normal \\
\hline Experiment & Thinking Skills Critical & 0,844 & Normal \\
\hline
\end{tabular}

Table 3 shows the results of testing variables thinking skills critical in control class and experiment class, where it is known that value of significance (Sig.) is equal to 0,702 and 0,844 . It can be concluded that value of significance (Sig.) > 0,05 , which means normal distribution of data.

Table 4: Results Normality Test Student Learning Outcomes

\begin{tabular}{|l|l|c|c|}
\hline Group & Variables & $\begin{array}{c}\text { Chi-Square } \\
\text { Test }\end{array}$ & $\begin{array}{c}\text { Information } \\
\text { (Asymp. Sig. }>\mathbf{0 , 0 5})\end{array}$ \\
\hline \multirow{2}{*}{ Control } & Pretest & 0,605 & Normal \\
\cline { 2 - 4 } & Posttest & 0,584 & Normal \\
\hline \multirow{2}{*}{ Experiment } & Pretest & 0,697 & Normal \\
\cline { 2 - 4 } & Posttest & 0,616 & Normal \\
\hline
\end{tabular}

The results in table 4 is known that significance (Sig.) values pretest student learning outcomes in amount of 0,605 to control class and amounted to 0,584 for experimental class, so that data on both class pretest normal distribution. While posttest on test results known that significance value (Sig.) of learning outcomes control class is 0,697 and experiment class at 0,616 . With significance (Sig.) $>0.05$ indicates that value of both classes posttest normal distribution.

\section{Homogeneity Test}

Homogeneity test performed on data thinking skills critical moment is treated as well as pretest and posttest in order to determine data bervarian same (homogeneous) or different. Homogeneity test data is calculated by using test Levene's Test. The results of data homogeneity test thinking skills critical and student learning outcomes as follows.

Table 5: Homogeneity Test Results Thinking Skills Critical

\begin{tabular}{|c|c|c|c|c|}
\hline Levene Statistic & $d f .1$ & $d f .2$ & Sig. & $\begin{array}{c}\text { Information } \\
\text { (Asymp. Sig. > 0.05) }\end{array}$ \\
\hline 0,286 & 1 & 42 & 0,679 & Homogeneous \\
\hline
\end{tabular}

Table 5 of the test results known that the significance value (Sig.) thinking skills critical control class and experiment class is $0,679>0,05$ so that it can be said to have the same or homogeneous variant.
Table 6: Homogeneity Test Results Student Results

\begin{tabular}{|l|c|c|c|c|c|}
\hline & $\begin{array}{l}\text { Levene } \\
\text { Statistic }\end{array}$ & $d \boldsymbol{f} \mathbf{1}$ & $d \boldsymbol{f} \mathbf{2}$ & Sig. & $\begin{array}{c}\text { Informati on } \\
\text { (Asymp. Sig. }>\text { 0.05) }\end{array}$ \\
\hline Pretest & 0,345 & 1 & 42 & 0,572 & Homogeneous \\
\hline Posttest & 0,057 & 1 & 42 & 0,887 & Homogeneous \\
\hline
\end{tabular}

Test the results table 6 is known that value of significance (Sig.) Student learning outcomes in pretest (control class and experiment class), namely 0,572 >0,05, which shows data pretest have the same variance (homogeneous). While at posttest test results known that significance value (Sig.) Student learning outcomes (control class and experiment class), namely $0,887>0,05$, which shows data posttest have the same variance (homogeneous).

\section{Results T-Test Data before Treatment}

Results T-Test data of student learning before briefly treated can be seen in table 7 below:

Table 7: Results of T-Test Data Pretest Student

\begin{tabular}{|c|c|c|c|c|}
\hline $\boldsymbol{T}_{\text {count }}$ & $\boldsymbol{T}_{\text {table }}$ & $\boldsymbol{d f}$ & Sig. (2-Tailed $)$ & $\boldsymbol{\alpha}$ \\
\hline 3,257 & 2,416 & 42 & 0,026 & 0,05 \\
\hline
\end{tabular}

T-test results in table 7 is known that $\mathrm{t}_{\text {count }}$ of 3,257 ( $d f$. 42) $<$ table 2,416 (df. 42) and Sig. (2-tailed) 0,026<0,05, which means that $H_{0}$ is accepted and $H_{a}$ rejected. These results indicate a significant difference between control class student learning outcomes with experiment class students.

\section{Results T-Test Data after Treatment}

Hypothesis test results of data thinking skills critical at time of treatment are briefly presented in following table:

Table 8: Results of Test-T Posttest Thinking Skills Critical

\begin{tabular}{|c|c|c|c|c|}
\hline $\boldsymbol{T}_{\text {count }}$ & $\boldsymbol{T}_{\text {table }}$ & $\boldsymbol{d f}$ & Sig. (2-Tailed $)$ & $\boldsymbol{\alpha}$ \\
\hline 3,114 & 2,442 & 42 & 0,014 & 0,05 \\
\hline
\end{tabular}

T-test results in table 8 for thinking skills critical when treatment (control class and experiment class) with a value $t_{\text {count }}$ of 3,114 (df. 42) and Sig. (2-tailed) of 0.014. These results indicate $\mathrm{t}_{\text {count }} 3,114(d f .42)>\mathrm{t}_{\text {table }}$ 2,442 (df. 42) and Sig. (2-tailed) 0,014 $<0.05$, which means that $\mathrm{H}_{0}$ refused and $\mathrm{H}_{\mathrm{a}}$ is received, which showed a significant difference in thinking skills critical in control class and experiment class.

Table 9: Results Hypothesis Posttest Student Learning Outcomes

\begin{tabular}{|r|r|c|c|c|}
\hline $\boldsymbol{T}_{\text {count }}$ & $\boldsymbol{T}_{\text {table }}$ & $\boldsymbol{d f}$ & Sig. (2-Tailed $)$ & $\boldsymbol{\alpha}$ \\
\hline 3,374 & 2,011 & 42 & 0,029 & 0,05 \\
\hline
\end{tabular}

T-test results in table 9 data posttest learning outcomes of students (control class and experiment class) it can be seen that $\mathrm{t}_{\text {count }} 3,374$ (df. 42) and Sig. (2-tailed) of 0,029. These results indicate $\mathrm{t}_{\text {count }} 3,374(d f .42)>$ table $^{2,011}(d f .42)$ and Sig. (2- 
tailed) $0,029<0.05$, which means that $\mathrm{H}_{0}$ refused and $\mathrm{H}_{\mathrm{a}}$ accepted. That is, there a significant difference in student learning outcomes in control class and experiment class.

\section{Results F-Test Data after Treatment}

Hypothesis test results of data critical thinking skills at the time of treatment are briefly presented in table 10 below:

Table 10: Results of F-Test Posttest Thinking Skills Critical and Student Learning Outcomes

\begin{tabular}{|c|c|c|c|c|}
\hline $\boldsymbol{F}_{\text {count }}$ & $\boldsymbol{F}_{\text {table }}$ & $\boldsymbol{d f}$ & Sig. (2-Tailed $)$ & $\boldsymbol{\alpha}$ \\
\hline 3,652 & 2,139 & 42 & 0,018 & 0,05 \\
\hline
\end{tabular}

T-test results in table 10 for thinking skills critical and student learning outcomes when treatment (control class and experimental class) with a value of $3,114 F_{\text {count }}(d f .42)$ and Sig. (2-tailed) of 0,014. These results indicate $F_{\text {count }} 3,652$ ( $d f$. 42) $>F_{\text {table }} 2,139$ (df. 42) and Sig. (2-tailed) 0,018<0,05, which means that $\mathrm{H}_{\mathrm{o}}$ refused and $\mathrm{H}_{\mathrm{a}}$ accepted. That is, there is a significant difference in thinking skills critical and student learning outcomes in control class and experiment class.

\section{CONCLUSION}

On the results of analysis average pretest and posttest value of thinking skills critical there are significant differences between control class and experiment class. In the control class is 71,2 while average value of thinking skills critical in experiment class of 78,6. These results were confirmed again by t-test is obtained $\mathrm{t}_{\text {count }} 3,114(d f .42)>\mathrm{t}_{\text {table }} 2,442(d f .42)$ with a significance level of $0,014<0,05$. This suggests that their differences of thinking skills critical in control class and experiment class. So we can conclude that Problem Based Learning model of significant effect on thinking skills critical in Social Sciences for $4^{\text {th }}$ grade in elementary school of Islam Nurul Hikmah Lebakadi village Sugio district, Lamongan regency.

In analysis of average pretest and posttest student learning outcomes are significant differences between control class and experiment class at posttest. In control class is 67,4 , while experiment class of 79,6 . The average value can be said to be difference in student learning outcomes of posttest between control class and experiment class, reinforced by t-test results are obtained $\mathrm{t}_{\text {count }} 3,374(d f .42)>\mathrm{t}_{\text {table }}$ 2,011 (df. 42) with significance level of $0,029<0,05$ this shows there difference in student

learning outcomes in control class and experiment class. So we can conclude that Problem Based Learning model of significant effect on students learning outcomes in Social Sciences for $4^{\text {th }}$ grade in Elementary School of Islam Nurul Hikmah Lebakadi village Sugio district, Lamongan regency.

In analysis of average pretest and posttest thinking skills critical and student learning outcomes are significant differences between the control class and the experiment class at posttest. In control class is 52,8 , while the experiment class of 81,9 . The average value can be said to be difference in value of thinking skills critical and student learning outcomes of posttest between control class and experiment class, reinforced by results of F-test is obtained $\mathrm{F}_{\text {count }} 3,652(d f .42)>\mathrm{F}_{\text {table }} 2,139(d f .42)$ with significance level of $0,018<0,05$. So it can be concluded that Problem Based Learning model significant effect on thinking skills critical and student learning outcomes in Social Science for $4^{\text {th }}$ grade of elementary school in SD Islam Nurul Hikmah Lebakadi village Sugio district, Lamongan regency.

\section{REFERENCES}

[1] T. R. C. Umbara, Undang-Undang Republik Indonesia Nomor 20 Tahun 2003 tentang Sistem Pendidikan Nasional dan Peraturan Pemerintah Republik Indonesia Tahun 2003 tentang Standar Nasional Pendidikan serta Wajib Belajar. Bandung: Citra Umbara, 2014.

[2] R. E. Slavin, Cooperative learning teori, riset dan praktik, vol. 236. Bandung, 2005.

[3] S. Kardi and M. Nur, Pengajaran langsung. 2000.

[4] S. P. Trianto and M. Pd, Model-model pembelajaran inovatif berorientasi Konstruktivistik. 2007.

[5] H. Abdul and J. Asep, Evaluasi Pembelajaran. 2012.

[6] A. Fisher, Critical thinking: An introduction. Cambridge: Cambridge University Press, 2011.

[7] R. M. Gagne, The conditions of learning. , New York: Holt, Rinehart \& Winston, 1970.

[8] J. R. Mergendoller, N. L. Maxwell, and Y. Bellisimo, "The effectiveness of problem-based instruction: A comparative study of instructional methods and student characteristics," Interdiscip. J. Probl. Learn., vol. 1, no. 2, p. 5, 2006.

[9] B. Akcay, "Problem-Based Learning in Science Education.," J. Turkish Sci. Educ., vol. 6, no. 1, 2009.

[10] D. Tillman, "Implications of Problem Based Learning (PBL) in elementary schools upon the K-12 engineering education pipeline," in 2013 ASEE Annual Conference \& Exposition, 2013, pp. 23-709.

[11] A. S. Argaw, B. B. Haile, B. T. Ayalew, and S. G. Kuma, "The Effect of Problem Based Learning (PBL) Instruction on Students' Motivation and Problem Solving Skills of Physics," EURASIA J. Math. Sci. Technol. Educ., vol. 13, no. 3, pp. 857-871, 2017.

[12] D. R. Sugiyono, Statistika untuk penelitian. 2006.

[13] A. Suharsimi, Prosedur penelitian suatu pendekatan praktik. 2006.

[14] D. Prayitno, "SPSS 22 Pengolahan Data Terpraktis," Yogyakarta CV. Andi Offset, 2014.

[15] T. Winarsunu, Statistik dalam penelitian psikologi dan pendidikan. Penerbitan Universitas Muhammadiyah Malang, 2002.

[16] R. Sundayana, "Statistika penelitian pendidikan," Bandung Alf., 2014.

[17] I. Suparyogo, "Metode Penelitian Kuantitatif Kualitatif dan R\&D," Bandung Alf., 2001. 